\title{
Rhetorical Analysis of an Organizational Artifact: A University's Response in Defense of Hate Speech
}

\author{
Samantha Okegbe* \\ Department of Communication, The University of Illinois at Urbana-Champaign, 702 S. Wright St. \\ Urbana, IL, 61801, USA. \\ * E-mail of the corresponding author: sokegbe2@illinois.edu
}

\begin{abstract}
In 2017, a hate speech flier targeting the LGBTQ community was posted in the main classroom building at Cleveland State University (CSU). This article explores the rhetoric surrounding the hate speech posted at this institution. The President's insensitive email response to this hate speech sparked outrage from students, faculty, staff, and the public. To correct his mistake, he delivered an apologia. In this study, I analyze the President's email response to the hate crime and his apology to the university. His apologia reveals strong evidence of emotional intelligence (pathos), an appeal to the university's credibility (ethos), and use of claims and evidence (logos) which were all lacking in his initial email to the hate speech.
\end{abstract}

Keywords: Hate speech, Rhetoric, Legitimacy, Institution

DOI: $10.7176 / \mathrm{NMMC} / 95-07$

Publication date: March $31^{\text {st }} 2021$

\section{Introduction}

On the 16th of October 2017, a flier was posted all over the main classroom building at Cleveland State University (CSU) targeting the lesbian, gay, bisexual, transgender, and queer or questioning (LGBTQ) community that stands for. These terms are used to describe a person's sexual orientation or gender identity (Russell et al, 2010). The flier showed an illustration of a man with a rope tied around his neck (see Appendix I for full image). The flier also displayed statistics of what it claimed were the percentages of suicides among the LGBTQ community. At the top of the flier, typed in bold letters above the man's head were the words, " $34 \%$ of trans people attempt suicide." By the left side of the flier, we can see the words typed in bold letters, " $30 \%$ of suicides are LGBT related." And on the right part of the flier, we can see the words in bold letters, "over $40 \%$ of bisexual people considered suicide." Finally, at the bottom, we can see a swastika-like symbol with the words "Fascist solutions" typed on the flier. What makes this situation interesting and a point of stasis is that the fliers were urging LGBTQ members to commit suicide. In his response released on the 17th of October 2017, CSU President Ronald M. Berkman did not condemn or criticize the fliers but rather he defended free speech. Activists, students, alumni and staff were infuriated and took to Twitter, Facebook and even classrooms to express their grievances (see Appendix II). They criticized the president's response and questioned the university's defense of the First Amendment and free speech.

For the community, this day marks a special day as the first LGBTQ center to be open at CSU. Prior to this time, there was not an LGBTQ center on campus. The whole campus was filled with unrest and curiosity as to who were the perpetrators and what the university was doing to address the matter. Officials took down the fliers but not before a few members of staff, students and possibly faculty had taken photos of the fliers. The opening of the center and the posting of the fliers set up the rhetorical exigence. Berkman's first message became part of the rhetorical situation, which is the basis of this analysis. The aim of this study is to conduct a rhetorical analysis of Berkman's replies. His inappropriate reply created a rhetorical situation that led to a rhetorical exigence. A rhetorical exigence according to Bitzer (1968) is not just a problem or deficiency, but one that is possible to do something about, possibly through rhetorical discourse. The President was heavily criticized for failing to condemn the homophobic flyers on campus.

Bitzer (1968) states that a situation and its constraints controls what can be said to change the exigence in question. An exigence is a defect or an obstacle that needs to be modified by discourse (Bitzer, 1968). In response to the exigence of the homophobic flyers, the president's rhetorical discourse was not effective in showing his disapproval towards the flyer and his support for the LGBTQ community. The aspect of this rhetorical situation which I conduct my analysis on is the President's messages which contributed to the exigency of the situation and how he subsequently delivered a discourse of defense, also known as an apologia. In this study, I conduct a rhetorical analysis of the President's initial message and his apologia that was delivered via email to all students, 
faculty, and staff. I critically examine the purpose of the rhetor, the President at CSU, his aim for the audience and the effectiveness of his uses of logos, ethos, and pathos to convey his message. I will start by analyzing his first response to the flier that caused a backlash and then I will analyze his apologia in defense to his first message. This study starts with an introduction of the rhetorical artefact, then the rhetorical situation, and the argument. The rest of the section that follows critically examines the impact of the artefacts and concludes with implications of the study.

\section{The Rhetorical Artifact}

In this organizational phenomenon, the rhetor is the president at Cleveland State University, Ronald Berkman. He was voted as the new president and assumed the position on July 1, 2009. According to Jones \& Baker (2019), there is an increase in uncivil, hate and bias incidents on college campuses. Hate speeches occurs regularly in organizations, especially in educational institutions. Hateful fliers have appeared in several campuses in the past few years. When issues like this are not responded to appropriately, they often lead to negative consequences like threats to the organization's identity and legitimacy. Organizational legitimacy is how organizations lose, meet, and regain societal approval, and act in accordance with public values (Deegan, 2002; Epstein, 1972; Francesconi, 1982). The identity of an organization is seen as its voice, that is, what represents the organization (Heath, Cheney, \& Ihlen, 2018). The president, who is also acting as the spokesperson for the university, takes the role of the rhetor. The first message can be typified as formal, impersonal, and internal as this was an official statement from the university sent to all members of staff, faculty, and students. The formality of the message can be seen from the first paragraph (see Appendix III to view full message):

"At Cleveland State University, our foremost priority is maintaining a welcoming environment that provides opportunities for learning, expression and discourse."

The message is impersonal: The rhetor frequently used "CSU", "we", and "our", to represent the whole institution. The President did not personalize the message to reflect his own emotions. This demonstrates a lack of pathos and shows how he avoided expressing his personal feelings about the situation. He avoided the use of the personal pronoun "I" to show either an acceptance or a displeasure at the hate speech directed towards the LGBTQ community expressed in the flyer. The goal of the rhetor in this artefact is to reiterate the stance, values, and identity of the organization. However, the message was not appropriate to address the situation. It set up an exigence that invited a response. Due to the backlash from the public, the president released a second statement, which was clearly more personal than the first statement. The goal of this second artefact was to maintain and reinforce the image, identity, and legitimacy of the organization which is focused on educational growth. For instance, the rhetor applied an ethos appeal by using verbal imagery to reinforce this goal and state what CSU aims to accomplish for all. This is evident in the third paragraph:

"CSU also is committed to upholding the First Amendment, even with regard to controversial issues where opinion is divided. We will continue to protect free speech to ensure all voices may be heard and to promote a civil discourse where educational growth is the desired result".

\section{The Rhetorical situation}

The exigence of this rhetorical situation helps to provide insight into the context of the rhetorical moment. A flier that was posted at CSU main classroom building urging LGBTQ students to commit suicide, led to a larger discussion on hate speeches and First Amendment rights on campus. The flyer was posted the same day a new center was opened for LGBTQ students at CSU. It is common for educational institutions like CSU to experience hate crime and speeches. College administrators in these institutions will typically criticize or condemn such hate speeches, which is a common expectation by their audience. However, the President at CSU initially fails to condemn the flyers but instead issued a statement lacking emotions via email to defend free speech, "CSU also is committed to upholding the First Amendment, even with regard to controversial issues where opinion is divided". He suggests that current legal framework makes it difficult for LGBTQ students to be protected from such hate messages. This accounts for reasons why his response to the exigency is to show support of free speech by upholding the First Amendment.

The recipients of the rhetorical message, the audience, are students, faculty, and staff of Cleveland State University. The unintended recipients are the activists, alumni, news outlets, people on social media and the public in general. They receive the initial message and respond to it in a way the President would not have predicted. These different 
audience members took to Twitter, Facebook, interviews, websites, and blogs to express their infuriation and disappointment. For instance, the Human Rights Campaign released a statement to Inside Higher Ed. "It's disappointing that CSU President Ronald Berkman failed to initially grasp the seriousness of the despicable antiLGBTQ flyers..." Another member of the audience felt the president's response was not sufficient to diffuse the situation. A junior at CSU, Molly Stachnik, who identifies as queer expressed her hurt by stating "We want to make our voices heard. We want to send a clear message to Berkman that we're not going to stand for this, that this is not OK, we're not going to let this get swept under the rug."

State and national organizations expressed their disappointment at the President's response. Alana Jochum who is the executive director of Equality Ohio, shows her disappointment and questioned how the flyer did not violate the university's antidiscrimination policy. She stated, "It is violence, it's targeting a specific population, and generally threats are not protected speech." Others feel the president did not show his disapproval at the hateful speech and his response is not appropriate. Lecia Brooks who is a director at the Southern Poverty Law Center stated clearly that this is not a free speech issue and that the president's response was very unacceptable. Others perceive his response as almost implying everyone had a freedom of speech, both hateful speeches included. Some other unintended audience that saw the President's initial message offered suggestions on what his message should have focused on. She is the executive director of the LGBT Community Center of Greater Cleveland, Phyllis Harris, suggest that, "The focus of this conversation should remain on the physical and psychological safety of Cleveland State's LGBTQ community and not on the rights of those who wish them harm." This clearly addresses the lack of pathos in the President's message which does not show empathy towards the affected victims of the hate speech. There are no constraints of how the rhetoric was delivered. As the President at CSU, there are limitless opportunities and platforms in which the message could have been delivered and communicated other than via email. For instance, in his second response (see Appendix 3), he set up a meeting at the school's auditorium to discuss the issue further, "I recognize this incident has created significant concern around the campus and invite you to join me and members of my staff tomorrow, October 18 at 2 p.m. in the Main Classroom Auditorium to discuss your concerns." For those who could not attend, he also suggested a different platform in which they can reach out to him directly, his email: “hi.president.berkman@csuohio.edu.” Nonetheless, in his second response, he explained that is initial message was as a result of legal constraints, "While I find the message of this poster reprehensible, the current legal framework regarding free speech makes it difficult to prevent these messages from being disseminated".

The purpose of analysis: Rhetorical analysis deals with argumentation, justification, and persuasion (Aristotle, 1984). The purpose of this rhetorical analysis is to explore and examine the strategies the rhetor uses to achieve his goals (Lasode et al., 2020; Oluwadara et al., 2020). This analysis will implement Aristotle's persuasive appeals, ethos, logos, and pathos to show how this rhetoric was ineffective (Oluwaseun et al., 2020). The analysis provides suggestions on ways this rhetoric could have been more effective. This analysis also aims to understand and judge what is revealed about the organization's presentation of itself, which includes its values, identity, and its legitimacy. And finally, this analysis examines his apologia and contrast the devices employed with his initial message.

The argument: The context of a situation matters in deciding if a logos appeal (to logic), pathos appeal (to emotion), or ethos appeal (to the persuader's character) is most appropriate to a particular audience (Ihlen \& Heath, 2018; Bizzell \& Herzberg, 1990).

\section{Ethos: Appeals to Organizational Credibility}

Artefact 1 is heavily loaded with ethos. The rhetor effectively employ strong ethos appeal in his message. The rhetor uses appropriate writing style by using formal language in his message to argue that CSU's foremost priority is "is maintaining a welcoming environment that provides opportunities for learning, expression and discourse." In using formal language such as professional and strong words that carries appropriate connotations, he establishes himself as a credible spokesperson for the university thus creating ethos.

In treating his audience with respect, Berkman employs ethos appeal by establishing some common grounds. He does this by acknowledging the university and the student's interests are aligned by "continuing to promote free speech to ensure all voices may be heard and to promote civil discourse where educational growth is the desired result." In establishing common grounds, he shows the university has the student's best interest at heart and is committed to upholding it. However, this does not seem to be effective as his audience do not feel their voices are heard.

Berkman wants the audience to believe the university is in support of freedom of speech for everyone on campus. 
However, what this does is to show support for all speech, including hate speech which should not be tolerated. The rhetor appeals to organizational credibility by using language that shows the organizations competence, sense of community and shared values. To persuade the audience of the organization's competence and credibility, the rhetor uses words like, "our foremost priority", "maintaining a welcoming environment", "fully committed", etc. This informs and reminds the audience of what the university is established to do and how it is continuing to maintain that environment.

To persuade the audience of the organizations sense of community, the rhetor uses language such as "committed", "campus community", "sense of inclusiveness", "our university," etc. The rhetor wants the audience to believe that the university is committed to fostering a sense of community on campus: "CSU remains fully committed to a campus community that respects all individual" To persuade the audience of the organizations shared values, the rhetor uses words like "free speech", "all voices", "educational growth." This is seen in the statement, "We will continue to protect free speech to ensure all voices may be heard and to promote a civil discourse where educational growth is the desired result."

\section{Pathos: Appeals to Emotion}

Berkman's statement lacks appeals to the emotions of his audience. His message does not utilize vivid language to engage his audience emotionally. There are no use of words to show empathy with the target audience of the hate speech. There was no show of disappointment towards the hateful speech, or a disapproval of the flyers that were posted on campus or empathy towards the LGBTQ community/students for being the target of the hate speech. This was suggested by some of the audience that the focus of the message should be on the physical and psychological safety of the LGBTQ students at CSU and not on the free speech rights. The values that was appealed to in the message was that of free speech. The rhetor uses terms such as "First Amendment", "free speech", to appeal to the audience values of freedom of speech. However, the rhetor fails to appeal to the needs of the audience which was to condemn the hate speech towards the LGBTQ community. He fails to appeal to their emotions and convince them of his empathy. To show a form of identification, the rhetor establishes common ground between the university and his audience. He uses "our" in his statement: "Be assured that a spirit of inclusiveness will always be central to the very identity of our University." He tries to use unifying symbols such as "CSU" and "inclusiveness" but fails to make all his audience feel inclusive as was evident from the backlash he received. His refusal to show his condemnation towards the hate speech as taken as a show of support towards the perpetrators.

\section{Logos: Use of Claims and Evidence}

In Berkman's message, there is a lack of appeal to logos. He does not effectively present strong claims and evidence in his statement. He makes inappropriate claims that the university is committed to "upholding the First Amendment, even with regard to controversial issues where opinion is divided." His claims are not appropriate for this rhetorical situation as free speech does not include hate speech. He also makes claims that CSU is a campus community that "respects all individuals, regardless of age, race, color, religion, national origin, sexual orientation and other historical bases for discrimination." His use of logic to make claims is ineffective as his message lacks evidence to support them. The ineffective logos appeal in his message is evident in the backlash he received from his audience. His audience are not convinced that CSU is a campus that respects all individuals. For instance, Molly who is an undergrad at CSU expresses how excluded she feels by stating, "We want to make our voices heard." An effective way to have appealed to his audiences' logical side would have been by presenting a line of reasoning in his argument. For instance, by using evidence such as statistics or factual information to show CSU has been fully committed in respecting all "individuals, regardless of age, race, color, religion, national origin, sexual orientation and other historical bases for discrimination." Another suggestion to the rhetor is to consider the audience that is heavily affected by the situation. By putting the LGBTQ students into consideration, his appeal to their reasoning would have been more effective.

\section{Stylistic Strategies}

Berkman employed some stylistic strategies in his statement. The structure of the text is logical and in a four paragraph and sequential order. He began his message by giving a polite conventional address to his intended audience: "Dear Students, Faculty and Staff". The sentence structure in the four paragraphs are declarative of what the university stands for and what it aims to uphold. Berkman employs formal language throughout his message. For example, he argues that CSU's foremost priority is "maintaining a welcoming environment that provides 
opportunities for learning expression and discourse." His choice of words are formal, and important terms are not repeated. For instance, his message was an effect of a hate speech, hence the importance of repeating terms like "respecting all individuals", "race", "sexual orientation", "inclusiveness" etc should be incorporated throughout the message. However, in his statement, he fails to address the situation that occurred which instigated his response. He employs ambiguity in his words and avoids making any direct claims of the situation. His words does not show support for neither of the parties but rather sounded vague. He uses formal diction throughout the initial message and uses long intricate sentences to express the formality of the message. He uses periods to end each of his paragraphs to show finality. The use of at least one exclamation mark at the end of a sentence should have been done to show emphasis especially when employing pathos appeal to show disappointment. The tone of the speech is objective, logical, and distant which may seem appropriate since he is the university representative. However, an empathetic tone would be more effective towards the target group. Berkman's message fails to fulfil his intention of letting the perpetrators know that the university frowns upon hate speech despite upholding the first amendment.

The form in which this rhetoric was presented was through mass email to all students, faculty and staff of the university. A more effective medium would have been face to face. For instance, hosting an event where all members of the LGBT community and the entire university can gather and discuss their grievances. Fortunately, within a day, he was able to give a second statement addressing the flyer issue specifically. He was able to show some appeal to logos by stating his disappointment at the hate speech. An effective text structure could have been in a cause and effect format. He could have started by stating what the cause was which was the hate speech posted on campus. Then he could have stated the drastic effects this may have had on the targeted LGBT students, the community, other students' and the university as a whole. He could have then proposed a solution or a platform for everyone to suggest possible solutions moving forward. He also employs the rhetorical trope synecdoche "CSU" to refer to the administrative body of the university.

\section{The impact of the artifact}

October 16th marked a special day for the LGBT community at CSU. However, the university failed in its attempt to show support for this community. The public, as well as students and staff of the university were not pleased with the way the president of the university handled the situation. Due to this public backlash, the president was prompted to send another response addressing the issue appropriately. He decided to change the form in which to present his rhetoric. He sent a second email to all members of the university and created an event where everyone could meet to discuss their concerns with him. This seems a more effective approach as opposed to the initial rhetoric he presented.

One major impact was the threat to the university's identity and legitimacy. Organizational identity is considered a set of enduring unique features that help form the basis of an organizational character (see Kuhn, 1997; Aust, 2004; Albert \& Whetten, 1985). Hoffman and Ford (2009) stated:

"Once an organization has completed the difficult task of crafting a positive and distinct identity, it must work to maintain that identity. Identity maintenance rhetoric consists of messages designed to preserve or enhance the identity of the organization in the face of anticipated or unanticipated identity - enhancing or - threatening events" (p. 127)

An organization must work to maintain its positively crafted identity by designing messages that will help preserve that identity in the case threatening events such as hate speeches. Berkman's initial message created an image of an organization different from the inclusive character it had created over the years. This created doubts in the minds of the audience which led to questions concerning the organizations values. The audience also plays a part in the building up of the organizations' identity. Cheney (1991) defines identity as the relationship between individuals and the social structures they belong or engage in.

Organizations operate in an environment of continuous and persistent criticism (Hearit, 1995). He adds reasons for this being the "gross inequities of size" between individuals and organizations. Individuals have no choice in leveling the playing field except by calling a company's social legitimacy into question. The legitimacy of CSU is threatened due to Berkman's initial message. His actions did not reflect the assumed values of the institution. When actions are not perceived to be congruent with social values, it leads to a crisis of legitimacy (Hearit, 1995; Esobi et al., 2020a). He adds that when organizations' values and responsibility is challenged, they must offer a discourse of reason to restore their legitimacy. 


\section{The Rhetorical Situation}

On 17 th of October 2017, exactly a day after the president's message instigated by the hate speech, he offered an apology. This was delivered exactly 20 hours after his first response to the hate speech that was posted on campus. This second response was more appropriate in comparison with the first message. Also, the timeline between both messages also shows the severity of the situation and how it required an apologia. The exigence that invited a response from the President was his message that was not sensitive to the LGBTQ community at CSU and declaring that CSU will always stand by the first amendment. In his initial message, he does not explicitly acknowledge the hate speech incident that occurred on campus. For instance, he uses ambiguous language to show CSU's commitment to uploading free speech even, "with regard to controversial issues where opinion is divided." Within hours of receiving the initial message from the president, the whole campus of students, staff, and faculty was agog with unrest. There was a widespread backlash both from intended and unintended audience members. Unintended audience included activist groups, alumni, external organizations, LGBTQ community etc. This situation prompted an apologia from the president.

\section{The Argument}

Corporate apologia is the "defense used in an attempt to redress the social legitimacy violation" (Hearit, 1994).

\section{Ethos: Appeal to Organizational Credibility}

Ethos is created by employing the use of memorable imagery and painting a verbal picture for your audience of what can be accomplished with their help (Emrich et al., 2001; Esobi et al., 2020b). In his apologia, the president employs ethos appeal. He does this by using appropriate writing style and connotations to show his competence in, "promoting a safe and inclusive campus for all members of our community." His statement also establishes his ability to uphold a sense of community for everyone on campus. In his apologia, he employs the use of the first person "I" throughout his message to show his perspective on the situation and the urgency to address the situation. For instance, "I recognize this incident has created significant concern around the campus and invite you to join me and members of my staff tomorrow." This is clearly in contrast to his consistent use of "we" in his initial message. While he uses a neutral voice in the initial message, he clearly takes a stand in his apologia. The use of "I", "personal outrage", "reprehensible" accurately conveys the positions of people with whom he disagrees with. He uses appropriate connotations in his message by addressing the community "LGBTQ+" appropriately. This creates an image of a good rhetor that is well-informed and genuinely interested in concerns affecting the LGBTQ community.

Berkman uses ethos appeal to successfully establish authority throughout his message by acknowledging his "personal outrage over a recent incident," restating his perspective by, "making it clear that I am committed to promoting a safe and inclusive campus" etc. This creates a sense of comfort and trust that the president can handle such situations. This is in contrast to his initial message which does not reflect his personal credibility and competence towards the exigency. President Berkman also acknowledges that the issue is one of complexity and difficulty. He does this by stating, "the current legal framework regarding free speech makes it difficult to prevent these messages from being disseminated." His official position and experience as the president gives credibility as someone that should be listened it concerning this issue.

\section{Pathos: Appeals to emotion}

The president's apologia is heavily loaded with pathos appeal. He effectively appeals to the emotions of his audience. He starts his message by admitting to a mistake on his part, "I wanted to acknowledge that yesterday I failed to express my personal outrage over a recent incident involving an anti-LGBTQ+ poster that was recently posted on campus". His writing style showing honest admittance of mistake evokes emotions of empathy and forgiveness in the heart of his audience. Additionally, he uses strong vivid language to show his distaste for the poster by calling it, "reprehensible," and his feelings towards it, "outrage." This is clearly different from his initial message that showed a total lack of language use to show his disappointment and outrage.

He clearly identifies the need to show empathy towards the targeted group, the need to show outrage towards the hate speech perpetrators, and also the need to show support and competence to keep the community safe. He explicitly appeals to values of inclusiveness and safety, "I am committed to promoting a safe and inclusive campus for all members of our community". The rhetor uses clear vivid language to show strong emotions of 
disappointment towards the flier that was posted.

\section{Logos: Use of Claims and Evidence}

Logos appeals to the audience's interest which helps to establish legitimacy and informs the audience of the value of what is being discussed. Berkman's second message does not show a strong appeal to logos. In compared with his first message, his second message does not utilize a claim and evidence structure. However, he gives a reason for his actions in the initial message. He states how despite finding the message reprehensible, "the current legal framework regarding free speech makes it difficult to prevent these messages from being disseminated.". This gives a logical explanation to his audience that some circumstances are beyond his control despite not being in support of such fliers.

\section{Stylistic strategies}

Berkman employs a few stylistic strategies in his apologia. The structure of the text is arranged into five short paragraphs. It follows a prose form of literary genre. Just like his initial message, he starts with a conventional form of address to his audience, "Dear Students, Faculty, and Staff." He starts off the message with a strong use of "I" as a form of identification and ownership of responsibility. This contrasts with his consistent use of "we" and "CSU" in his initial message. The style of Berkman's writing is persuasive as he tries to convince his audience of his point of view which is his apology, "I recognize this incident has created significant concern around the campus." This reflects understanding, respect, and the common grounds he shares with his audience.

The impact of the Apologia: The form in which the apologia is presented is through email. One strategic way he delivered this appeal and was more effective than his initial message, was his arrangement of public meeting with everyone. Having a face to face meeting to addressing the situation further, shows concern and a sense of shared values. When organizations are faced with an accusation of misdeed, rhetors have five available paths to negotiate their crises (Benoit, 1995; Esobi et al., 2021). They could deny, evade responsibility, reduce the offensiveness of an event, utilize corrective action, or engage in self-mortification or a combination thereof. Berkman employs the use of the second approach in his initial message. In this approach, he worked to escape responsibility and uses vague language to avoid responding to the issue directly. Benoit states that some apologists will claim that events beyond their control conspired against them. For instance, in Berkman's statement, "While I find the message of this poster reprehensible, the current legal framework regarding free speech makes it difficult to prevent these messages from being disseminated."

Benoit (1995) suggests using corrective action and mortification as an effective path to negotiating crises. This is a more effective approach than reducing offense or evading responsibility. In corrective action, crisis managers use the strategy of reassurance and a promise to fix the cause of the crises. In mortification, they acknowledge responsibility, apologize, and seek forgiveness. Berkman starts his second message with a strong use of mortification which sets a tone of forgiveness, "I wanted to acknowledge that yesterday I failed to express my personal outrage over a recent incident involving an anti-LGBTQ+ poster that was recently posted on campus". He also uses the evading responsibility strategy as he disassociates himself from the situation.

\section{Conclusion and Implications}

This analysis is significant to institutions that may experience hate speeches in their various campuses. The artefacts discussed in this study shows an example of an ineffective and effective approach to managing issues in an institution through discourse. This study also has implications for corporate and professional organizations. The public relations representatives and the marketing department can learn from this study and implement the rhetorical strategies discussed like pathos, ethos, and logos that may be used to effectively persuade their audience. This will also help the public relations department to know how and when to incorporate pathos appeals in sensitive situations and topic. As evident from Berkman's initial message, the lack of pathos caused a backlash from his audience which led to the university's identity and legitimacy to be questioned. Nevertheless, he was able to effectively utilize mortification in his apology to his audience. Hearit (1995) adds that the goal of an apologetic discourse is not just forgiveness but a public acknowledgement of a wrongdoing. Additionally, the public acknowledgement is complete when the context has a performance component which moves the narrative through a logical and moral conclusion. 


\section{References}

Abimbade, Oluwadara and Philip, Olayoku and Herro, Dani, (2020). Millennial Activism within Nigerian Twitterscape: From Mobilization to Social Action of \#ENDSARS Protest. Available at SSRN: https://ssrn.com/abstract=3760973 or http://dx.doi.org/10.2139/ssrn.3760973

Albert, S., \& Whetten, D. A. (1985). Organizational identity. Research in organizational behavior. Aristotle, J., Barnes, J. A., \& Smith, W. D. (1984). The Complete Works of Aristotle the Revised Oxford Translation/Edited by Jonathan Barnes.

Aust, P. J. (2004). Communicated values as indicators of organizational identity: A method for organizational assessment and its application in a case study. Communication studies, 55(4), 515-534.

Bitzer, L. (1968). The rhetorical situation. Philosophy \& Rhetoric, 1(1), 1-14.

Bizzell, P., \& Herzberg, B. (Eds.). (1990). The rhetorical tradition: Readings from classical times to the present. Boston, MA: Bedford Books of St. Martin's Press.

Cheney, G. (1991). Rhetoric in an organizational society: Managing multiple identities. University of South Carolina Press.

Danielle Herro, Cassie Quigley, Holly Plank \& Oluwadara Abimbade (2021) Understanding students' social interactions during making activities designed to promote computational thinking, The Journal of Educational Research, DOI: 10.1080/00220671.2021.1884824

Deegan, C. (2002). The legitimizing effect of social and environmental disclosures: a theoretical foundation. Accounting, Auditing, \& Accountability Journal 15(3), 282-231.

Emrich, C. G., Brower, H. H., Feldman, J. M., \& Garland, H. (2001). Images in words: Presidential rhetoric, charisma, and greatness. Administrative Science Quarterly, 46(3), 527-557.

Epstein, E. M. (1972). The historical enigma of corporate legitimacy. California Law Review, 60, 1701-1718.

Esobi, I. C., Lasode, M. K., Anyanwu, C. I., Degbe, E., Barriguete, M. F., Okorie, M. A., ... \& Okegbe, S. (2020b). Nutritional Impact of COVID-19 and Its Implications on Atherosclerosis. World, 8(1), 16-21.

Esobi, I. C., Lasode, M. K., Anyanwu, C. I., Barriguete, M. F., Okorie, M. A., \& Lasode, D. O. (2021). Food Insecurity, Social Vulnerability, and the Impact of COVID-19 on Population Dependent on Public Assistance/SNAP: A Case Study of South Carolina, USA. Journal of Food Security, 9(1), 8-18.

Francesconi, R. A. (1982). James Hunt, the Wilmington 10, and institutional legitimacy. Quarterly Journal of Speech, 68, 47-59.

Hearit, K. M. (2006). Crisis management by apology: Corporate response to allegations of wrongdoing. Mahwah, NJ: Lawrence Erlbaum.

Hearit, K. M. (1995). "Mistakes were made": Organizations, apologia, and crises of social legitimacy. Communication Studies, 46(1-2), 1-17.

Hoffman, M. F., \& Ford, D. J. (2009). Organizational rhetoric: Situations and strategies. Sage Publications.

Ihlen, O., \& Heath, R. L. (Eds.). (2018). The Handbook of Organizational Rhetoric and Communication. John Wiley \& Sons.

Jones, C., \& Baker, R. A. (2019). Report on the uncivil, hate and bias incidents on campus survey.

Kuhn, T. (1997). The discourse of issues management: A genre of organizational communication. Communication Quarterly, 45(3), 188-210.

Oluwaseun, O., Tolulope, F. , Lukuman, B. , \& Ikechukwu, E. C. (2020). Improving Pre-service Teachers’ Memory and Retention Using Durable Memory Strategies in an Instructional Technology Course. American Journal of Educational Research, 8(11), 847-855.

Russell, S. T., Horn, S., Kosciw, J., \& Saewyc, E. (2010). Safe schools policy for LGBTQstudents and commentaries. Social Policy Report, 24(4), 1-25. 